\title{
Bilateral persistent sciatic arteries: a rare anatomical variant
}

\author{
Mumun Sinha, Niraj Nirmal Pandey, Rengarajan Rajagopal, Priya Jagia
}

Department of Cardiovascular Radiology and Endovascular Interventions, All India Institute of Medical Sciences, New Delhi, Delhi, India

\section{Correspondence to Dr Priya Jagia;} drpjagia@yahoo.com

Accepted 26 December 2019

\section{DESCRIPTION}

A 32-year-old woman, known case of chronic myeloid leukaemia on chemotherapy, presented with acute onset of bilateral foot pain and paraesthesia. On examinations, the pedal pulses were absent bilaterally with reduced cutaneous temperatures over the ankles and feet. Lower limb arterial Doppler examination revealed the absence of colour flow in the distal parts of bilateral anterior and posterior tibial arteries. Interestingly, bilateral common femoral arteries and the superficial femoral arteries (SFA) appeared uniformly small in calibre.

An immediate magnetic resonance angiography was performed, which revealed presence of bilateral complete persistent sciatic arteries (PSA) with small calibre/hypoplastic bilateral SFAs having no continuity with the respective popliteal arteries. Distal thrombotic occlusion of bilateral anterior and posterior tibial arteries was observed (figures 1 and 2). No significant stenosis was seen in the abdominal aorta, iliac or popliteal arteries. The patient was started on intravenous heparin following which there was significant resolution in symptoms. Follow-up Doppler examination after 2 weeks showed complete recanalisation of the distal tibial arteries.

PSA is a rare arterial embryologic anomaly reported in $0.03 \%-0.06 \%$ of the population and represents failure of regression of the embryonic sciatic artery, which is a branch of the umbilical
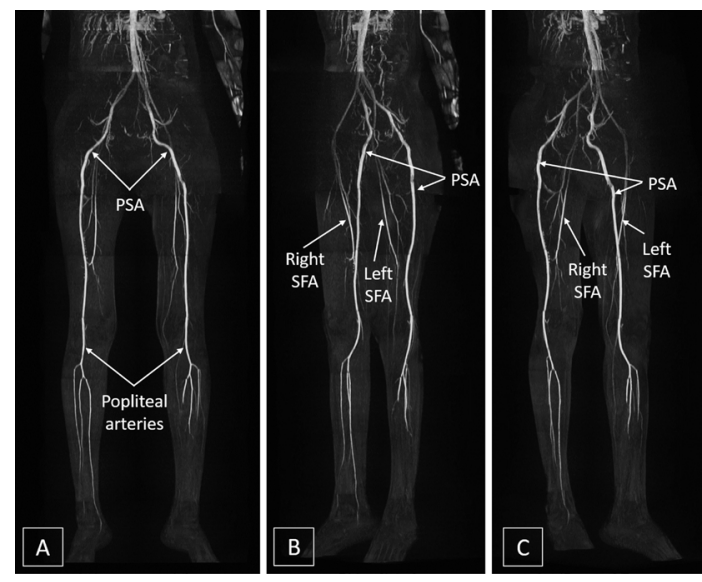

Figure 1 Maximum intensity projection images of magnetic resonance angiography $(A-C)$ reveals the presence of bilateral complete persistent sciatic arteries (PSA) with hypoplastic bilateral superficial femoral arteries (SFA) having no continuity with the respective popliteal arteries. Distal thrombotic occlusion of bilateral anterior and posterior tibial arteries is also present.
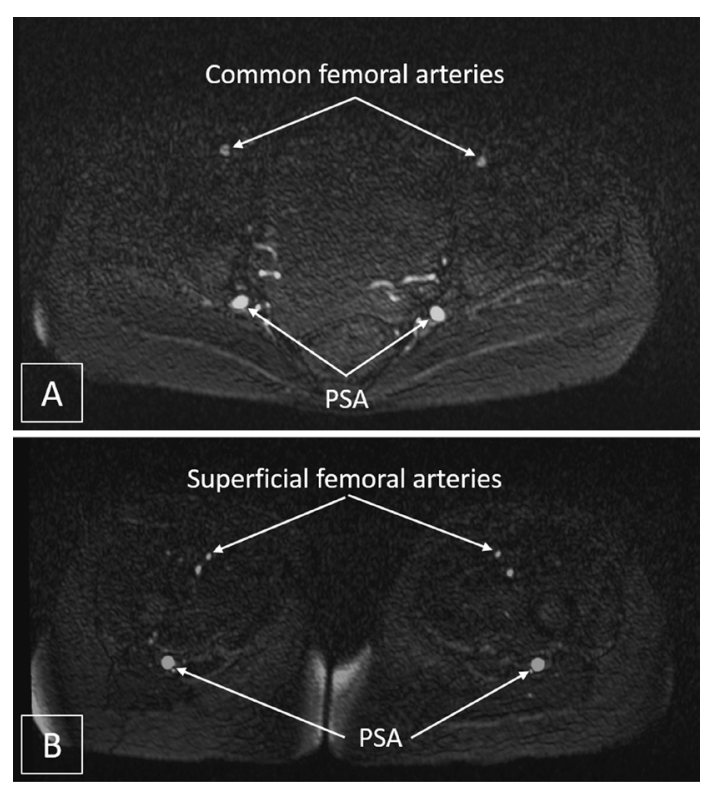

Figure 2 Axial magnetic resonance angiography images at the level of groin (A) and upper thigh (B) reveals the presence of bilateral complete persistent sciatic arteries (PSA) with hypoplastic bilateral common and superficial femoral arteries (SFA).

artery and the principal arterial supply of the developing lower limb. ${ }^{1}$ Most of the cases have unilateral anomaly with bilateral PSAs representing only about $30 \%$ of all cases.

Complete PSA (where it is the main blood supply to the lower limb or popliteal and infrapopliteal branches) is much more common than incomplete. In the presence of a complete PSA, the SFA may be normal (type 1), incomplete (type $2 \mathrm{a}$ ) or absent (type $2 \mathrm{~b}$ ). In the presence of incomplete PSA (types 3 and 4), the femoral arteries are normally developed. ${ }^{2}$ Though PSAs are prone to early atheromatous degeneration and aneurysm formation, most

Learning points

- Persistent sciatic artery (PSA) is a rare arterial embryologic anomaly representing failure of regression of the embryonic sciatic artery, which is the principal arterial supply of the developing lower limb.

- Most cases are unilateral with bilateral PSAs representing less than one-third of all the cases.

- Though PSAs are prone to early atheromatous degeneration and aneurysm formation, most often they are asymptomatic. 
often they are asymptomatic. The etiologies associated with a symptomatic PSA are aneurysm, PSA occlusion, PSA stenosis and distal occlusions, in decreasing order of frequency. In cases of isolated symptomatic distal occlusions, a trial of thrombolysis/ anticoagulation can be therapeutic, while other etiologies may require various combinations of medical, surgical and endovascular approaches.

Twitter Rengarajan Rajagopal @rengadr

Contributors MS, NNP, RR and PJ have participated sufficiently in the conception of the idea, the development of the intellectual content, design and writing and the final approval of the manuscript.
Funding The authors have not declared a specific grant for this research from any funding agency in the public, commercial or not-for-profit sectors.

Competing interests None declared.

Patient consent for publication Obtained.

Provenance and peer review Not commissioned; externally peer reviewed.

\section{REFERENCES}

1 van Hooft IM, Zeebregts CJ, van Sterkenburg SMM, et al. The persistent sciatic artery. Eur J Vasc Endovasc Surg 2009;37:585-91

2 Pillet J, Albaret P, Toulemonde JL, et al. Ischio-popliteal artery trunk, persistence of the axial artery. Bull Assoc Anat 1980;64:97-110.

Copyright 2020 BMJ Publishing Group. All rights reserved. For permission to reuse any of this content visit

https://www.bmj.com/company/products-services/rights-and-licensing/permissions/

BMJ Case Report Fellows may re-use this article for personal use and teaching without any further permission.

Become a Fellow of BMJ Case Reports today and you can:

- Submit as many cases as you like

- Enjoy fast sympathetic peer review and rapid publication of accepted articles

- Access all the published articles

Re-use any of the published material for personal use and teaching without further permission

Customer Service

If you have any further queries about your subscription, please contact our customer services team on +44 (0) 2071111105 or via email at support@bmj.com.

Visit casereports.bmj.com for more articles like this and to become a Fellow 